\title{
Immunohistological Studies of Metabotropic Glutamate Receptor Subtype 6-Deficient Mice Show No Abnormality of Retinal Cell Organization and Ganglion Cell Maturation
}

\author{
Yoshiaki Tagawa, ${ }^{1}$ Hajime Sawai, ${ }^{2}$ Yoshiki Ueda, ${ }^{1}$ Masaki Tauchi, ${ }^{2}$ and Shigetada Nakanishi ${ }^{1}$ \\ ${ }^{1}$ Department of Biological Sciences, Kyoto University Faculty of Medicine, Yoshida, Sakyo-ku, Kyoto 606-8501, Japan, \\ and ${ }^{2}$ Department of Welfare System and Health Science, Okayama Prefectural University, Kuboki, Souja, \\ Okayama 719-1197, Japan
}

Immature retinal ganglion cells (RGCs) initially show a multistratified dendritic pattern, and, during the postnatal period, these dendrites gradually monostratify into ON and OFF sublaminae. The selective agonist of group III metabotropic glutamate receptors (mGluR), L-2-amino-4-phosphonobutyrate (L-AP-4), hyperpolarizes ON bipolar cells and reduces glutamate release. On the basis of L-AP-4-evoked inhibitory effects on ON-OFF segregation of developing RGCs, it has been hypothesized that glutamate-mediated synaptic activity is crucial for formation of the ON-OFF network. Gene-targeted ablation of mGluR6 specifically expressed in ON bipolar cells blocks normal ON responses but has been predicted to enhance glutamate release from ON bipolar cells. The mGluR6 knockout mouse therefore provides a unique opportunity to investigate whether glutamate release and $\mathrm{ON}$ responses are important factors in the development of ON-OFF segregation. The combination of several different morphological analyses indi- cates that ON bipolar cells, as well as several distinct amacrine cells, in mGluR6 knock-out mice are normally distributed and correctly extend their terminals to defined retinal laminae. Importantly, both $\alpha$ and $\delta$ RGCs in adult mGluR6 knock-out mice are found monostratified into cell type-specific layers. Furthermore, no difference between wild-type and mGluR6 knock-out mice is observed in the maturation and dendritic stratification of developing RGCs. Hence, despite a deficit in normal ON responses, mGluR6 deficiency causes no abnormality in the retinal cellular organization nor in the stratifications of both ON bipolar cells and developing and mature RGCs. Based on these findings, we discuss several possible mechanisms that may underlie ON-OFF segregation of RGCs.

Key words: metabotropic glutamate receptor subtype 6; knock-out and transgenic mice; Lucifer yellow injection; immunohistology; ON response; dendritic stratification; retinal cells
Visual information is segregated into parallel $\mathrm{ON}$ and $\mathrm{OFF}$ pathways at retinal bipolar cells (Miller and Slaughter, 1986; Dowling, 1987; Schiller, 1992; Nakanishi, 1995). This segregation results from two different types of glutamate receptors: L-2amino-4-phosphonobutyrate (L-AP-4)-sensitive metabotropic glutamate receptor (mGluR) for ON bipolar cells and AMPAkainate receptors for OFF bipolar cells (Nawy and Jahr, 1990, 1991; Shiells and Falk, 1990; Yamashita and Wässle, 1991; de la Villa et al., 1995; Nakanishi, 1995; Sasaki and Kaneko, 1996). Light hyperpolarizes photoreceptors, resulting in a reduction of glutamate release. The reduction of glutamate release renders AMPA-kainate receptors inactive and hyperpolarizes OFF bipolar cells. In ON bipolar cells, mGluR also shows reduced activity such that the downstream signaling elements, G-protein and cGMP phosphodiesterase, remain in an inactive state. As a result, cGMP reaches high levels, thereby activating cGMP-gated ion channels and depolarizing ON bipolar cells. Thus, opposite

\footnotetext{
Received Oct. 13, 1998; revised Jan. 12, 1999; accepted Jan. 14, 1999.

This work was supported in part by research grants from the Ministry of Education, Science, and Culture of Japan, the Sankyo Foundation, the Yamanouchi Foundation, and the Biomolecular Engineering Research Institute. We thank Yutaka Fukuda for helpful advice and Kumlesh K. Dev for careful reading of this manuscript.

Correspondence should be addressed to Shigetada Nakanishi, Department of Biological Sciences, Kyoto University Faculty of Medicine, Yoshida, Sakyo-ku, Kyoto 606-8501, Japan.

Copyright (C) 1999 Society for Neuroscience $\quad 0270-6474 / 99 / 192568-12 \$ 05.00 / 0$
}

responses to light exposure are evoked in ON and OFF bipolar cells.

In the mature retina, the dendrites of $\mathrm{ON}$ and $\mathrm{OFF}$ retinal ganglion cells (RGCs) stratify at different levels in the inner plexiform layer (IPL) (Famiglietti and Kolb, 1976; Nelson et al., 1978; Peichl and Wässle, 1981). ON RGCs form synaptic contacts with ON bipolar cells at the inner part of the IPL (sublamina b), whereas OFF RGCs synapse onto OFF bipolar cells at the outer part of the IPL (sublamina a) (Wässle and Boycott, 1991). In early retinal development, immature RGCs possess multistratified dendrites, and these dendrites gradually monostratify into distinct sublamina during retinal development (Maslim and Stone, 1986, 1988; Dann et al., 1988; Ramoa et al., 1988). It has been reported that intraocular injection of L-AP-4, which hyperpolarizes ON bipolar cells, effectively suppresses the stratification process of RGCs in developing retina (Bodnarenko and Chalupa, 1993; Bodnarenko et al., 1995; Bisti et al., 1998). On the basis of these and other studies, it has been hypothesized that RGC dendritic remodeling results from activity-dependent glutamate release from ON bipolar cells.

Considerable evidence has indicated that mGluR6 is essential for evoking ON responses in both rod and cone systems. mGluR6 is confined at the postsynaptic site of ON bipolar cells and selectively responds to L-AP-4 (Nakajima et al., 1993; Nomura et al., 1994). Importantly, ablation of mGluR6 by gene targeting abolishes ON responses recorded from optic nerve terminals, as well as the b-wave of electroretinogram that reflects ON bipolar 
cell activity (Masu et al., 1995). Furthermore, loss of mGluR6 function results in marked impairments in both detecting weak contrasts and responding rapidly to light intensity (Iwakabe et al., 1997). The mGluR6 knock-out mouse therefore provides a useful model to test whether glutamate release from ON bipolar cells is involved in the formation of the ON-OFF network in the IPL and whether the $\mathrm{ON}$ response might be an important factor in $\mathrm{ON}-\mathrm{OFF}$ segregation.

In this investigation, we addressed whether mGluR6 deficiency causes any alteration in the retinal organization of bipolar, amacrine, and ganglion cells. We also examined whether impairment of ON responses affects development and stratification of immature RGCs during early retinal development. Here, we report that, despite a marked deficit of ON responses, mGluR6 knockout mice show no abnormality in the cellular organization of various retinal cells nor in the stratifications of ON bipolar cells and developing and mature RGCs.

\section{MATERIALS AND METHODS}

Animals. Homozygous mGluR6 knock-out mice that expressed the $\beta$-galactosidase (lacZ) transgene in ON bipolar cells under control of the mGluR6 promoter were generated by mating mGluR6 knock-out mice (Masu et al., 1995) with lacZ transgenic mice (Ueda et al., 1997). Homozygous disruption of the mGluR6 gene and integration of the lac $Z$ gene were confirmed by Southern blot hybridization as described previously (Masu et al., 1995; Ueda et al., 1997).

$X$-gal and immunofluorescence stainings. X-gal staining was performed in PBS supplemented with $1 \mathrm{mg} / \mathrm{ml} \mathrm{X-gal,} 35 \mathrm{~mm} \mathrm{~K}_{3} \mathrm{Fe}(\mathrm{CN})_{6}, 35 \mathrm{~mm}$ $\mathrm{K}_{4} \mathrm{Fe}(\mathrm{CN})_{6}, 2 \mathrm{~mm} \mathrm{MgCl}$, and $0.02 \%$ Nonidet P-40 as described previously (Ueda et al., 1997). Immunofluorescence staining was performed according to the procedures described previously (Nomura et al., 1994). The primary antibodies (Abs) used were as follows: mouse monoclonal Abs (mAbs) against protein kinase C (PKC) $\alpha$-isoform (MC5; 1:100 dilution; Amersham, Buckinghamshire, UK), choline acetyltransferase (ChAT) (1:250; Chemicon, Temecula, CA) and calbindin-D28K (CL300; 1:200; Sigma, St. Louis, MO); and rabbit polyclonal antibodies against lacZ (1:100; Cappel, Durham, NC), calretinin (1:2000; Chemicon), and tyrosine hydroxylase (TH) (1:100; Chemicon). Antibodies used for different mGluR subtypes were as described previously (Shigemoto et al., 1997). Secondary antibodies used were as follows: Texas Red (TR)$\mathrm{X}$-conjugated goat $\operatorname{lgGs}$ against rabbit $\lg \mathrm{g}$ (Rab-TRX) and mouse $\lg G$ (1:200; Molecular Probes, Eugene, OR); fluorescein isothiocyanate (FITC)-conjugated goat $\operatorname{lgG}$ against rabbit $\operatorname{lgG}$ (1:200; Cappel); and FITC-conjugated horse $\operatorname{lgG}$ against mouse $\lg$ (1:200; Vector Laboratories, Burlingame, CA). Biotinylated goat lgGs against rabbit $\lg G$ and mouse $\lg \mathrm{G}$ (1:200; Vector Laboratories) were used in some experiments and reacted with FITC-conjugated avidin D (1:1000; Vector Laboratories).

Intracellular injection of Lucifer yellow. Intracellular injection of Lucifer yellow CH (LY) (Sigma) into RGCs was performed as described previously (Tauchi and Masland, 1984). Young (postnatal day 12) and adult (7-8 weeks) mice were killed under deep anesthesia with diethylether, and eyes were removed. Incision was made along an edge of the sclera, and the retina with the lens was removed and immersed in an oxygenated Ames' medium (A1420; Sigma). The lens and vitreous body were removed, and the isolated retina was spread on a filter paper (No. 50; Whatman, Kent, UK), photoreceptor cell-side upward. After rinsing in Ames' medium, the retina was mounted ganglion cell-side upward onto a black filter paper (HABP; Millipore, Bedford, MA), placed in a superfusion chamber on the stage of an Olympus Opticals (Tokyo, Japan) BH2 microscope, and perfused with Ames' medium at a flow rate of $0.6 \mathrm{ml} / \mathrm{min}$ at $30^{\circ} \mathrm{C}$. Two drops of Acridine Orange $(0.001 \%$ in Ames' medium; Sigma) were added into the chamber to visualize somata in the ganglion cell layer (GCL). A glass micropipette (GC120F-10; Clark Electromedical Instruments, Reading, UK) was inserted into RGC somata under blue-violet excitation. These cells were completely filled with $5 \% \mathrm{LY}$ in $0.1 \mathrm{M} \mathrm{LiCl}$ by passing $2-4 \mathrm{nA}$ negative currents $(150 \mathrm{msec}$ at $4 \mathrm{~Hz}$ ) for 2-5 min. Usually, 15-20 RGCs per retina were successfully filled with LY.

Tissue processing and data analysis. LY-injected retinae were immersed overnight in a fixative containing $4 \%$ paraformaldehyde in $0.1 \mathrm{~m}$ sodium phosphate buffer. After several washes with the above buffer, the retinae were cryoprotected in $25 \%$ sucrose overnight and then subjected to freeze $\left(-80^{\circ} \mathrm{C}\right)$-thaw $\left(37^{\circ} \mathrm{C}\right)$ four times to improve antibody penetration. The retinae were preincubated with solution A (10\% normal goat serum, $0.5 \%$ bovine serum albumin, and $0.5 \%$ Triton X-100 in PBS) for $4 \mathrm{hr}$ and then incubated with TH-Ab in solution A for 1-2 d. After a $4 \mathrm{hr}$ washing by gently shaking, the retinae were incubated with Rab-TRX for 1 day, washed for $4 \mathrm{hr}$, then mounted on a slide glass, coverslipped, and sealed with nail enamel. All procedures were performed at $4^{\circ} \mathrm{C}$ unless otherwise stated.

Flat-mounted retinae were analyzed with the Olympus Fluoview confocal microscopy system. Serial images $(0.7-1 \mu \mathrm{m}$ in $z$-sections) were taken from the GCL to the border between the IPL and the inner nuclear layer (INL). The plane of the GCL was identified by visualizing the somata of RGCs and vessels located in the GCL. The plane of the IPL-INL border was identified on the basis of dendritic trees of THAb-immunostained dopaminergic cells. Serial images were processed, and images of the dendritic spread and of the dendritic stratification were reconstructed on $x-y$ and $x-z$ planes, respectively.

Stratification levels of RGC dendritic trees were quantified as follows: for each cell, serial images ( $z$-sections) were transferred to NIH Image software. The pixels above background levels were counted for each image and then represented as a percentage of the $z$-section that contained the highest pixel count. For each image, this digital processing was well correlated with direct measurement of dendritic lengths.

\section{RESULTS}

\section{Stratification of bipolar cell axon terminals}

Figure $1 A$ shows a scheme that illustrates the localization of somata and stratifications of both dendrites and axon terminals of retinal cells analyzed in this investigation. The characteristic distribution of these cells in the retinal cellular organization is discussed in each section described below. We first examined the localization and stratification of bipolar cells by crossing mGluR6 knock-out mice with transgenic mice expressing lac $Z$ under control of the mGluR6 promoter ( $\left.\mathrm{mGluR6}^{-/-} / \mathrm{lac}^{+}\right)$. In a previous study (Ueda et al., 1997), we showed that the mGluR6 promoter is capable of recapitulating a specific expression of $l a c Z$ in $\operatorname{rod}$ and cone $\mathrm{ON}$ bipolar cells. In addition, when the lac $Z$ protein was analyzed by X-gal staining or lacZ immunostaining, these transgenic mice displayed a clear stratification of lac Z-positive axon terminals of both rod and cone ON bipolar cells at the sublamina b. As shown in Figure 1, $B$ and $C$, we confirmed that punctate and intense mGluR6 immunoreactivity was observed in retinal sections of mGluR6 ${ }^{+/+} / \mathrm{lacZ}^{+}$mice but was completely lost in those of $\mathrm{mGluR6}^{-1-} / \mathrm{lac} \mathrm{Z}^{+}$mice.

We examined and compared the pattern of X-gal staining and lac $Z$ immunoreactivity in transverse retinal sections of $\mathrm{mGluR6}^{-/-} / \mathrm{lac}^{+}$and $\mathrm{mGluR6}{ }^{+/+} / \mathrm{lac}^{+}$mice. In both genotypes, X-gal-positive somata were located at the outer portion of the INL (Fig. $2 A, B$ ). These cells extended X-gal-positive axon terminals to sublamina $\mathrm{b}$ of the IPL. Furthermore, these axon terminals were separated into two levels at sublamina $b$. Intense $\mathrm{X}$-gal reaction products were observed in the inner part of sublamina $b$, whereas diffuse X-gal products were detected in the outer part of sublamina $b$. The former and the latter stainings corresponded to axon terminals of rod bipolar cells and cone ON bipolar cells, respectively. This pattern of X-gal staining was indistinguishable between mGluR6 ${ }^{+/+} /$lac $^{+}$and mGluR6 $^{-/-}$/ lac $Z^{+}$mice. The segregation of axon terminals of rod and cone ON bipolar cells was more explicitly observed in both genotypes by double immunostaining of lac $Z$ and PKC (Fig. 2C,D). PKC is a specific marker for rod bipolar cells (Negishi et al., 1988), thereby distinguishing between rod and cone $\mathrm{ON}$ bipolar cells. The axon terminals of lacZ-positive/PKC-positive rod bipolar cells resided in the innermost part of the IPL close to the GCL, 


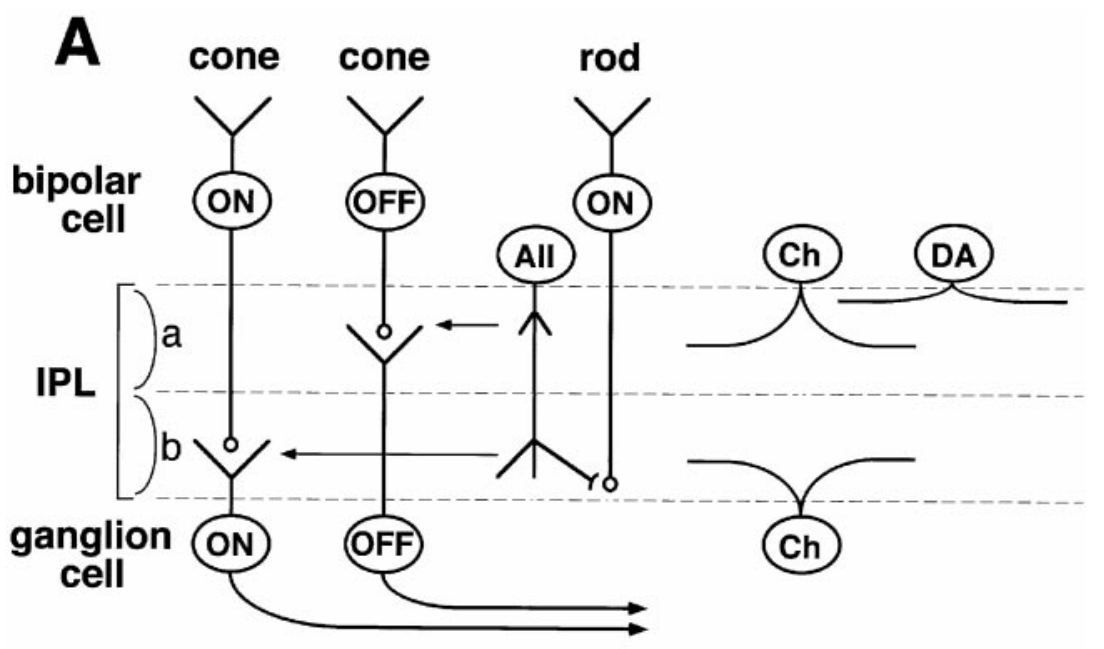

Figure 1. Schematic drawing of retinal cells and immunostaining of mGluR6. $A$, The distribution and dendritic and axonal stratifications of retinal cells. Cone ON bipolar cells make synaptic contacts with ON RGCs in sublamina $b$, whereas cone OFF bipolar cells form synaptic connections with OFF RGCs in sublamina a. Rod bipolar cells extend their axons to the innermost part of sublamina $\mathrm{b}$, where they make synaptic contacts with AII amacrine cells $(A I I)$. AII amacrine cells form gap junctions onto cone $\mathrm{ON}$ bipolar cells and also project inhibitory outputs onto cone OFF bipolar cells and OFF RGCs. $a$, Sublamina a; $b$, sublamina b; $C h$, cholinergic amacrine cell; $D A$, dopaminergic amacrine cell. $B, C$, Immunostaining of mGluR6 in transverse retinal sections of mGluR6 ${ }^{+/+} / \mathrm{lacZ}^{+}$and mGluR6 ${ }^{-/-} / \mathrm{lac}^{+}$mice. Punctate and intense mGluR6 immunoreactivity observed in the OPL of mGluR6 ${ }^{+/+} / \mathrm{lac}^{+}$mice was absent in mGluR6 $^{-1-} /$ lac $^{+}$mice. Scale bar, $20 \mu \mathrm{m}$.
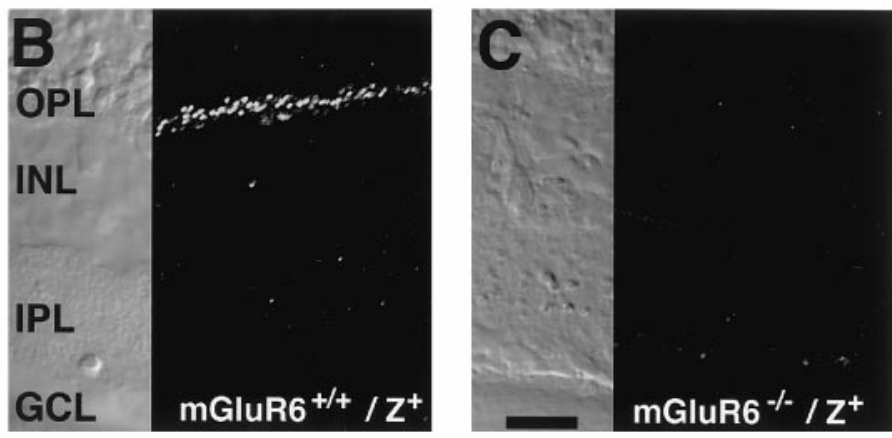

whereas those of lacZ-positive/PKC-negative cone ON bipolar cells were located at the outer half of sublamina b. Axonal stratifications of both rod and cone ON bipolar cells were unchanged by ablation of mGluR6 expression.

Because appropriate markers for mouse cone OFF bipolar cells were not available (Ueda et al., 1997), the stratification pattern of these cells remains to be determined. However, in this study, wild-type and knock-out mice showed a comparable width of sublamina a, where cone OFF bipolar cells form synaptic contacts with RGCs (Fig. $2 A, B$ ). This finding suggests that cone OFF bipolar cells send their axons to the appropriate place in mGluR6 knock-out mice. Because the lac $Z$ transgene expression provided a good marker for ON bipolar cells, we used and compared mGluR6 ${ }^{+/+} /$lac $^{+}$and mGluR6 ${ }^{-/-} /$lac $^{+}$mice as wild-type and mGluR6 knock-out mice in all subsequent experiments.

\section{Immunohistological characterization of amacrine cells}

Many amacrine cells stratify distinctly at the IPL. To examine the effect of mGluR6 deficiency on stratification patterns of amacrine cells, we analyzed several distinct amacrine cells, which were well characterized by immunostaining of specific markers. Cholinergic amacrine cells represent a well known subpopulation of amacrine cells that form synaptic contacts with RGCs at the IPL. When these cells were characterized with ChAT-mAb (Voigt, 1986; Mitrofanis et al., 1988), ChAT-positive somata were separately located in GCL and INL, and their dendrites were segregated into two strata in the IPL: one in the middle of sublamina a and the other in the middle of sublamina $\mathrm{b}$ (Fig. $3 A, B$ ). This pattern of immunopositive somata and two dendritic stratifications was unchanged between wild-type and mGluR6 knock-out mice.

Immunostaining patterns of two other classes of amacrine cell containing different calcium-binding proteins (Pasteels et al., 1990) were also indistinguishable between the two genotypes. Calretinin-immunoreactive somata were observed in both the INL and GCL, and three immunopositive bands were seen in the IPL (Fig. 3C,D). Double immunostaining with ChAT-mAb and calretinin antibody showed that the upper and lower bands, as well as some somata, were immunoreactive with both antibodies (Fig. $3 C, D$ ), indicating that a subpopulation of calretinin-positive amacrine cells are cholinergic amacrine cells. Horizontal cells were strongly immunostained with calbindin-D28K antibody (Fig. $3 E, F)$. Moreover, weak immunoreactivity in some somata of the INL and two weak bands in the IPL were observed in both genotypes with this antibody. Additionally, dopaminergic amacrine cells showed a common innervation pattern between the two genotypes as described below. The immunohistological characterization thus indicates that there is no difference in the cellular organization nor in the stratification pattern of several representative amacrine cells in mGluR6 knock-out mice.

\section{Expression patterns of mGluR subtypes}

Of eight different mGluR subtypes known presently, all but mGluR3 have been shown to be expressed and distinctly localized in different cell types of the rat retina (Shigemoto et al., 1992; Nakajima et al., 1993; Ohishi et al., 1993; Akazawa et al., 1994; Nomura et al., 1994; Duvoisin et al., 1995; Hartveit et al., 1995; Brandstätter et al., 1996; Koulen et al., 1996, 1997). It has been reported that ablation of a specific gene alters expression patterns of closely related genes (Hummler et al., 1994; Blendy et al., 1996). We therefore addressed this possibility by immunostaining with antibodies directed against different mGluR subtypes. Im- 


\section{mGluR6 ${ }^{+/+} / \mathrm{Z}^{+}$}
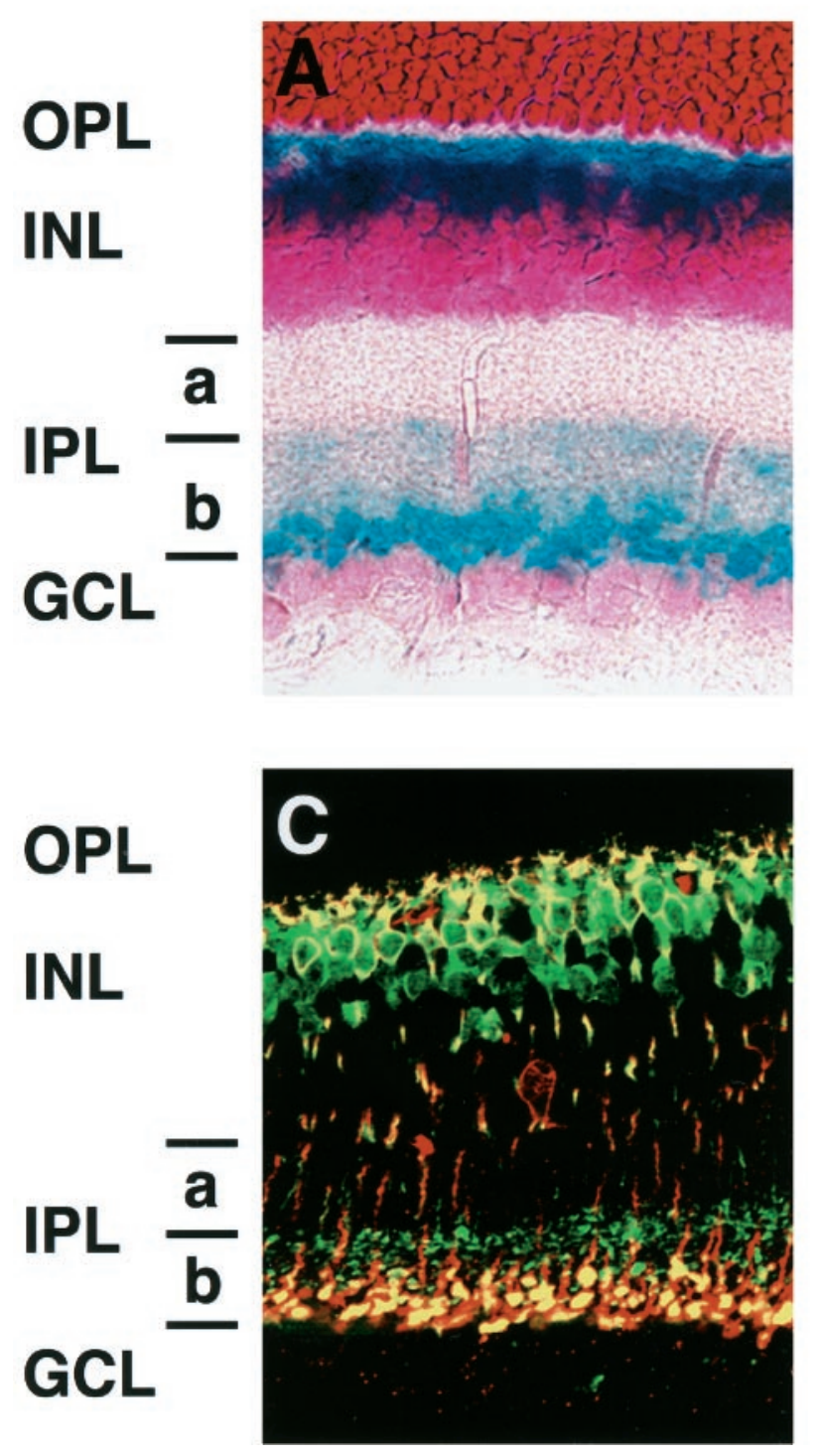

\section{mGluR6 ${ }^{-/-} / Z^{+}$}
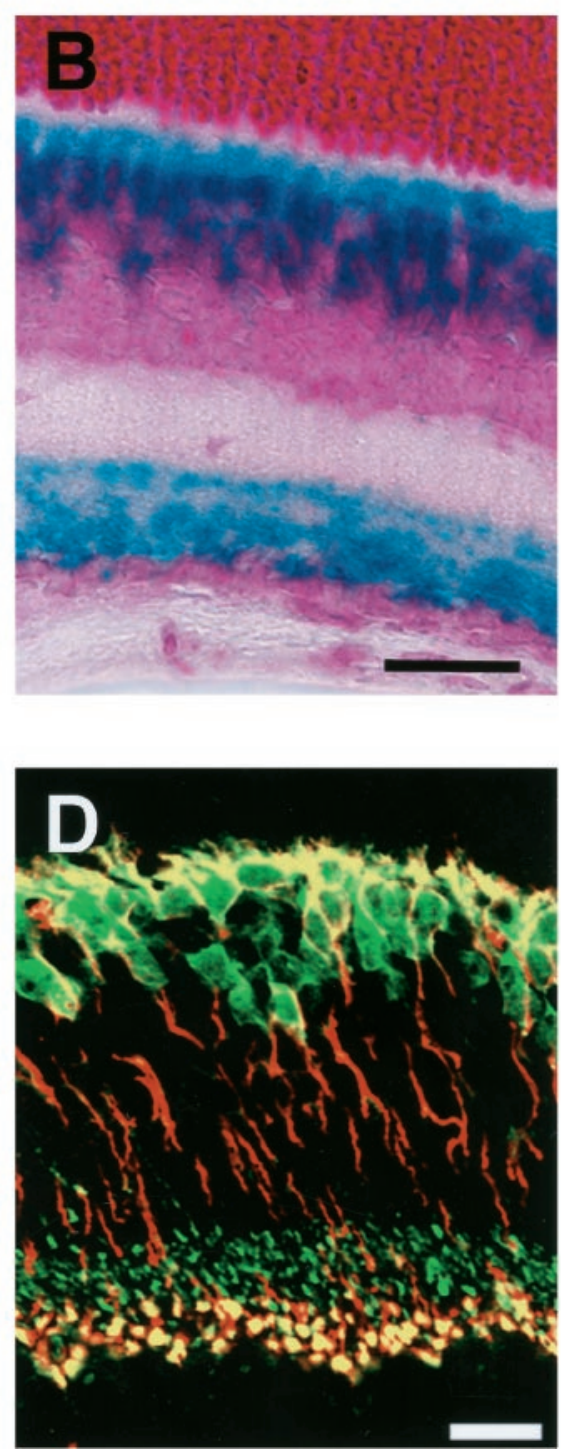

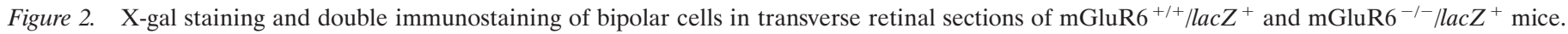

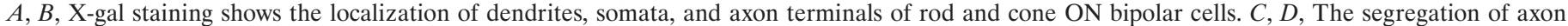

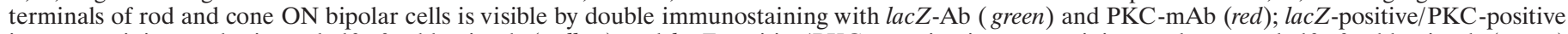

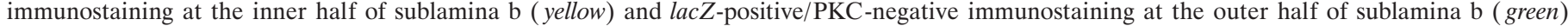
represent axon terminals of rod bipolar cells and cone ON bipolar cells, respectively. Scale bars, $20 \mu \mathrm{m}$.

munostaining of $\mathrm{mGluR} 1 \alpha$ showed a strong immunoreactivity at the inner part of the IPL and a weak immunoreactive band at the outer part of the IPL (Fig. $4 A, B$ ). mGluR5a immunoreactivity was weaker and was seen at the outer plexiform layer (OPL) and IPL (Fig. 4C,D). Two strong bands and one diff use but weak band of mGluR2 immunoreactivity were observed at the IPL (Fig. $4 E, F)$. In agreement with previous data (Koulen et al., 1996), the two bands at the IPL were immunostained with both ChAT-mAb and mGluR2-Ab, indicating that mGluR2 is localized in the processes of cholinergic amacrine cells. It has been reported that mGluR4 is localized at the postsynaptic targets of cone and rod bipolar cells in the rat retina (Koulen et al., 1996). Consistent with this observation, mGluR4a was seen at the IPL (Fig. 4G,H). However, whether a weak signal detected at the OPL was a specific immunoreaction to $\mathrm{mGluR} 4 \mathrm{a}$ remained unclear. mGluR8 immunoreactivity was clearly seen at the IPL and separated into two bands (Fig. 4I,J). The important conclusion of this analysis is that there is no obvious difference in the expression patterns of mGluR1 $\alpha$, mGluR2, mGluR4a, mGluR5a, and mGluR8 between the two genotypes.

In both wild-type and mGluR6 knock-out mice, mGluR7a immunostaining revealed two major immunoreactive bands at the outer part of the IPL and two diff use but weak bands at the inner part of the IPL (Fig. $4 K, L$ ). Interestingly, distinct immunoreactive patches of mGluR7a were detected at the OPL of mGluR6 knock-out mice (Fig. 4L). Because this mGluR7a expression at the OPL was specific for mGluR6 knock-out mice, we pursued the cellular origin of this mGluR7a expression. Double immunostain- 


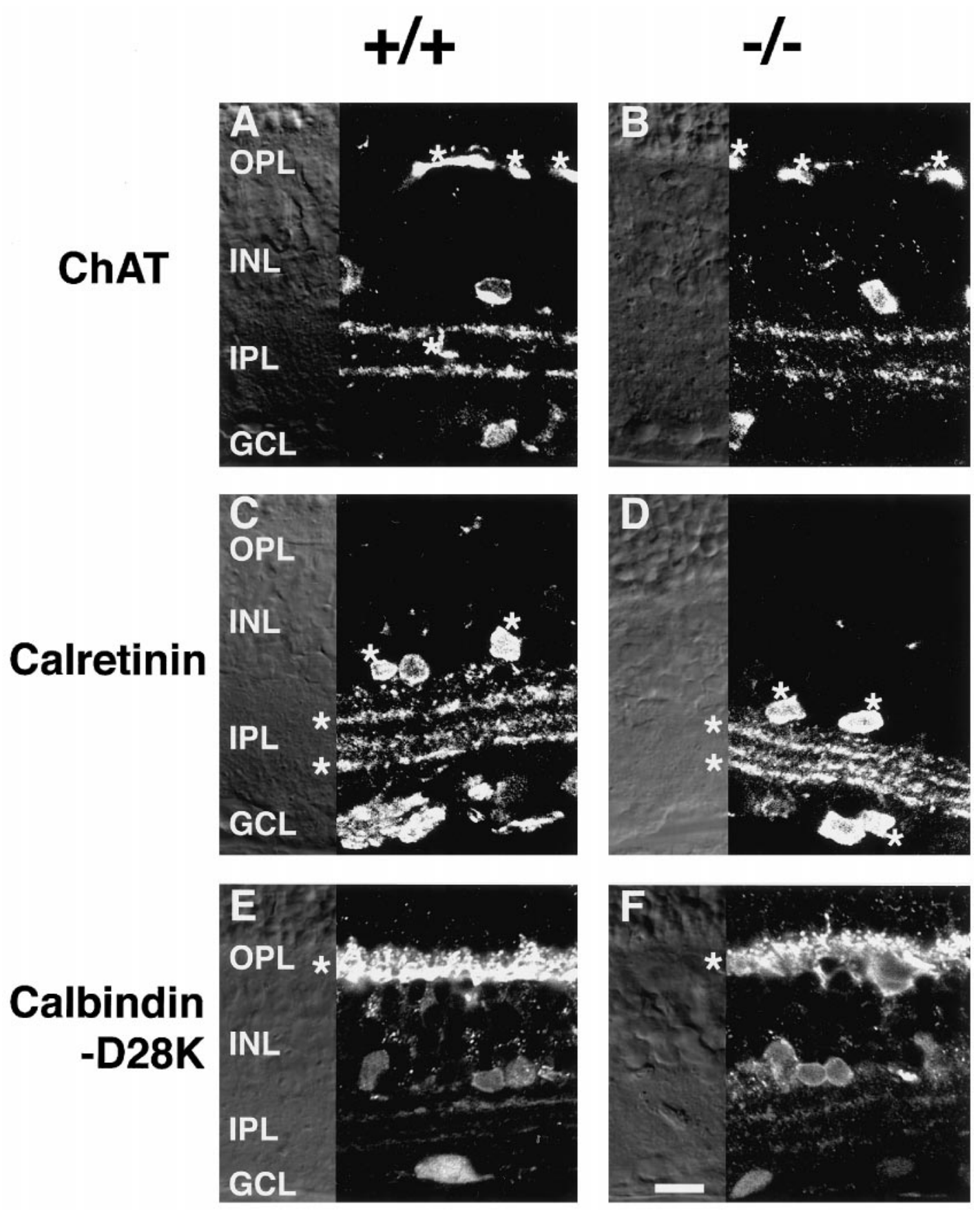

Figure 3. Immunostaining of several amacrine cell markers in transverse retinal sections of wild-type $(+/+)$ and mGluR6 knock-out $(-/-)$ mice. $A$, $B$, ChAT immunoreactivity. Blood vessels are marked by asterisks. $C, D$, Calretinin immunoreactivity. Calretinin-positive/ChAT-positive bands and somata as revealed by double immunostaining with calretinin antibody and ChAT-mAb are marked by asterisks. E, F, Horizontal cells in the OPL show intense calbindin-D28K immunoreactivity (asterisks). Scale bar, $20 \mu \mathrm{m}$.

ing with the mGluR7a and PKC antibodies showed no overlap of the two immunoreactivities (data not shown), suggesting that rod bipolar cells are not responsible for ectopic expression of mGluR7a at the OPL. Because lac $Z$ is expressed in cone ON bipolar cells (Ueda et al., 1997), we double-immunostained dissociated mGluR6 ${ }^{-/-} /$lac $Z^{+}$bipolar cells with the mGluR7a and lac $Z$ antibodies and attempted to visualize a possible colocalization of mGluR7a immunoreactivity at dendritic tips of cone ON bipolar cells. However, we found that cone bipolar cells were fragile during cell dissociation and failed to detect intact dendritic tips of dissociated cone bipolar cells. The origin of this expression awaits further investigation.

\section{Dendritic morphology and stratification of mature RGCs}

We then addressed whether mGluR6 deficiency in ON bipolar cells causes any change in dendritic morphology and stratification levels of RGCs. RGCs consist of a heterogeneous cell population that can be subdivided into several morphological and functional classes (Boycott and Wässle, 1974). We injected LY intracellu- 


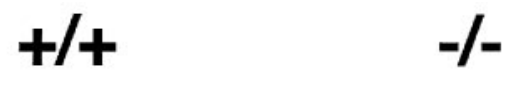

mGluR1 $\alpha$

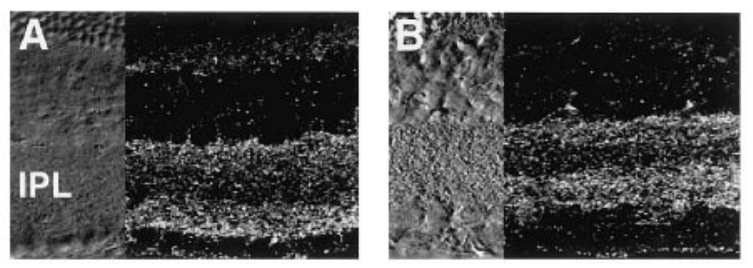

mGluR5a
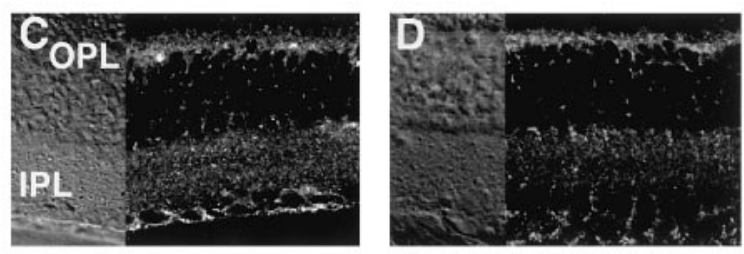

mGluR2

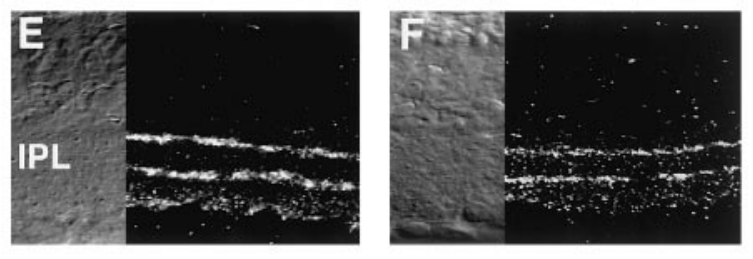

mGluR4a

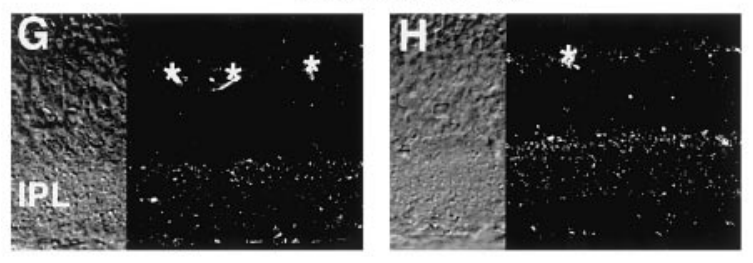

\section{mGluR8}

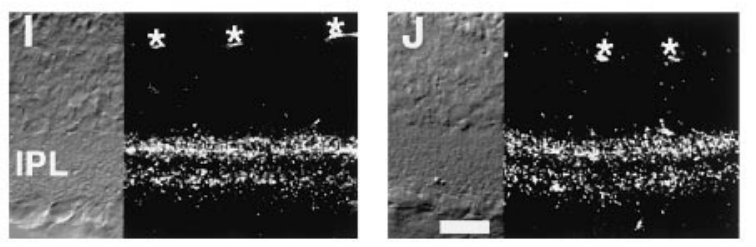

\section{mGluR7a}

$+/+$
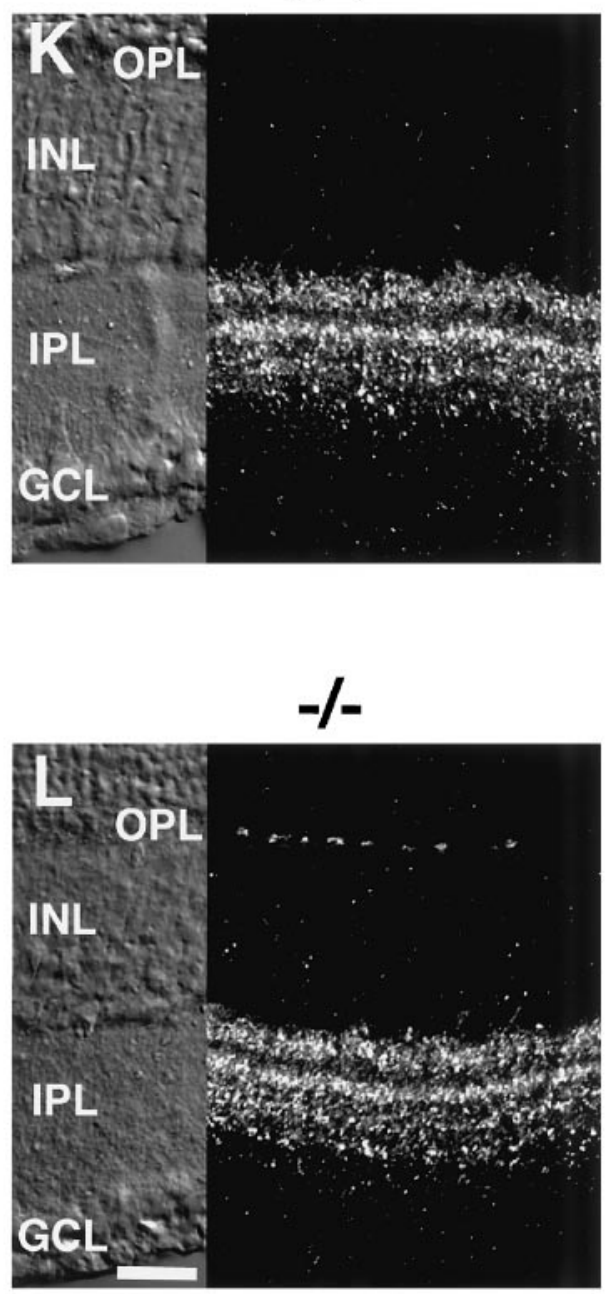

Figure 4. Immunostaining of different mGluR subtypes in transverse retinal sections of wild-type $(+/+)$ and mGluR6 knock-out $(-/-)$ mice. Immunoreactivities of mGluR1 $\alpha(A, B)$, mGluR5a $(C, D)$, mGluR2 $(E, F)$, mGluR4a $(G, H)$, mGluR8 $(I, J)$, and mGluR7a $(K, L)$. Note that mGluR7a immunoreactivity can be seen at the OPL of mGluR6 knock-out $(L)$ but not in wild-type $(K)$ mice. For other subtypes, no difference in the immunostaining patterns is observed between the two genotypes. Asterisks in $G-J$ show immunostaining of blood vessels. Scale bars, $20 \mu \mathrm{m}$.

larly into RGCs and analyzed the dendritic morphology and stratification levels of different types of RGCs. Among many different cell types observed, we focused on RGCs with mediumto large-sized somata ( $>20 \mu \mathrm{m}$ in diameter) because they showed a relatively simple morphology with monostratified dendrites at the IPL. Using the classification of RGCs reported in the rat retina as a reference (Peichl, 1989; Tauchi et al., 1992), we found stained cells that corresponded to $\alpha$ and $\delta$ cells on the basis of dendritic branching patterns and dendritic stratification levels.

$\mathrm{ON}$ and OFF bipolar cells distinctly terminate their axons at sublamina $b$ and sublamina a, respectively. Inner and outer RGCs stratify their dendrites at sublamina $b$ and sublamina a, respectively, and are thought to correspond to ON and OFF RGCs (Famiglietti and Kolb, 1976; Nelson et al., 1978; Peichl and Wässle, 1981). It is therefore critical to precisely assign stratification levels of individual LY-injected RGCs. When retinal sections were immunostained with TH-Ab (Mitrofanis et al., 1988; Wulle and Schnitzer, 1989), the dendritic innervation of dopaminergic amacrine cells was seen to run along the border of the IPL-INL (Fig. 5A,B). Furthermore, whole-mount retinal prep- 


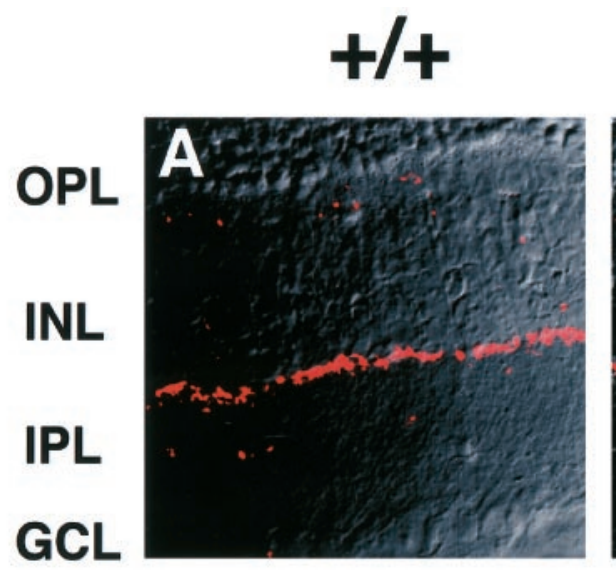

inner- $\alpha$
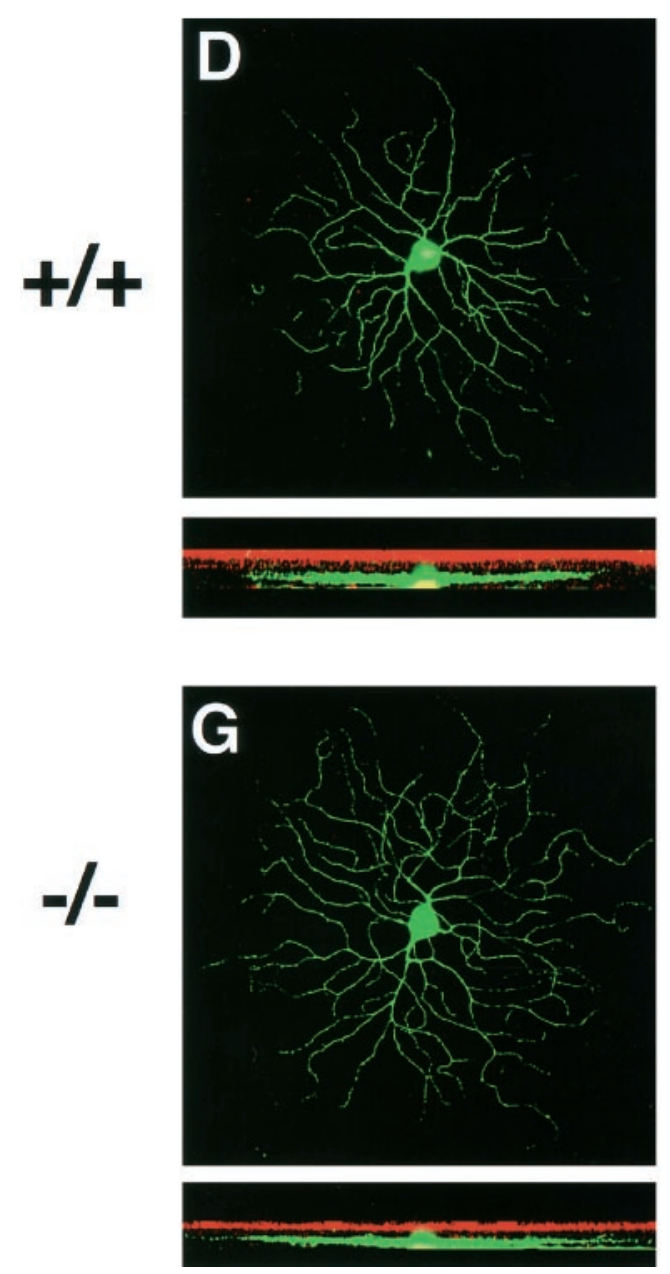

$-1$
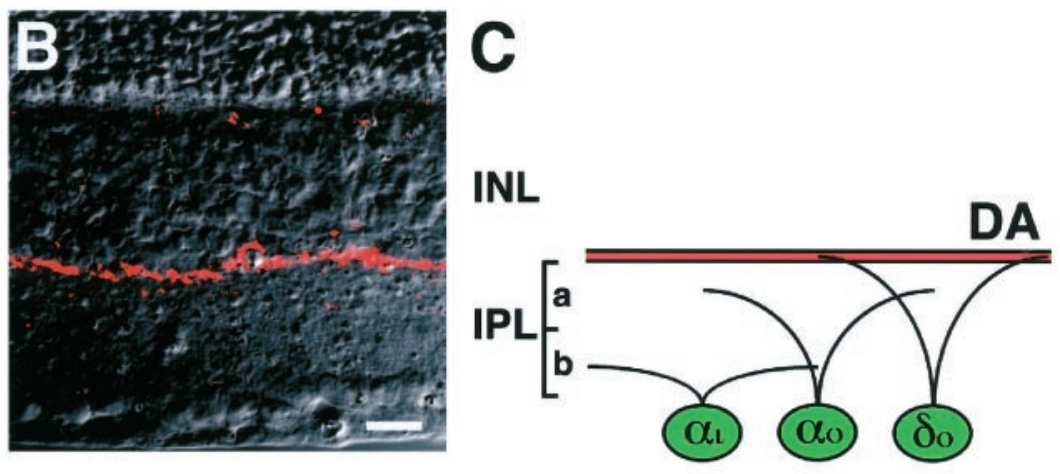

outer- $\delta$
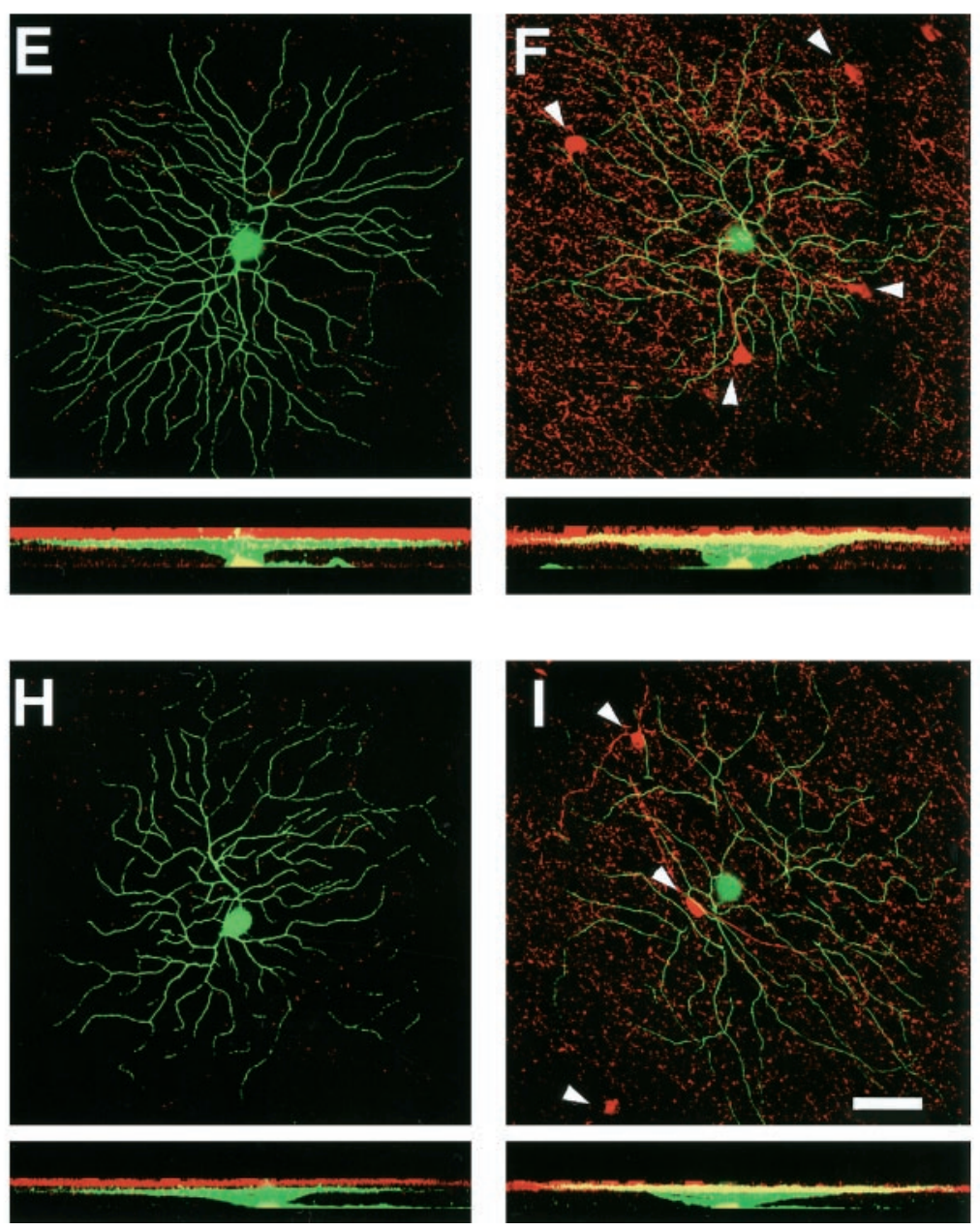

Figure 5. Dendritic morphology and stratification levels of inner- $\alpha$, outer- $\alpha$, and outer- $\delta$ RGCs in adult wild-type $(+/+)$ and mGluR6 knock-out $(-/-)$ mice. $A, B$, Dopaminergic amacrine cells immunostained with TH-Ab (red) were observed along the INL-IPL border in transverse sections of the two genotypes. This immunostaining was used as a reference to assign stratification levels of three types of RGCs $(D-I)$. $C$, Stratification levels of three RGCs are schematically illustrated; $\alpha i$, inner- $\alpha$ RGC; $\alpha o$, outer- $\alpha$ RGC; $\delta o$, outer- $\delta$ RGC; $D A$, dopaminergic amacrine cell innervation. $D-I$, In each panel, the top shows a confocal image of dendritic branches of three cell types on the main dendritic $x-y$ plane, and the bottom displays a reconstructed image on the $x-z$ plane. Note that the $x-z$ plane was processed to cut the GCL at the middle of RGC somata, thus they appear to protrude toward the IPL in $D$ and $G$. green, LY-injected RGCs; red, immunostained dopaminergic amacrine cells. Somata of dopaminergic amacrine cells are indicated by arrowheads in $F$ and $I$. $J-O$, Stratification levels and the distribution of dendritic branches of three cell types. For each cell, dendritic branches on each $z$-section taken from the GCL to the IPL-INL border (left to right in the abscissa) were represented as a percentage of the $z$-section containing the highest pixel count. The data were obtained from three types of RGCs shown in $D-I$. Eccentricity: $D, 1.6 \mathrm{~mm} ; E, 1.7 \mathrm{~mm} ; F, 1.8 \mathrm{~mm} ; G, 1.3 \mathrm{~mm} ; H$, $1.9 \mathrm{~mm} ; I, 1.6 \mathrm{~mm}$. Scale bars: B, $20 \mu \mathrm{m} ; I, 50 \mu \mathrm{m}$. Figure 5 continues. 


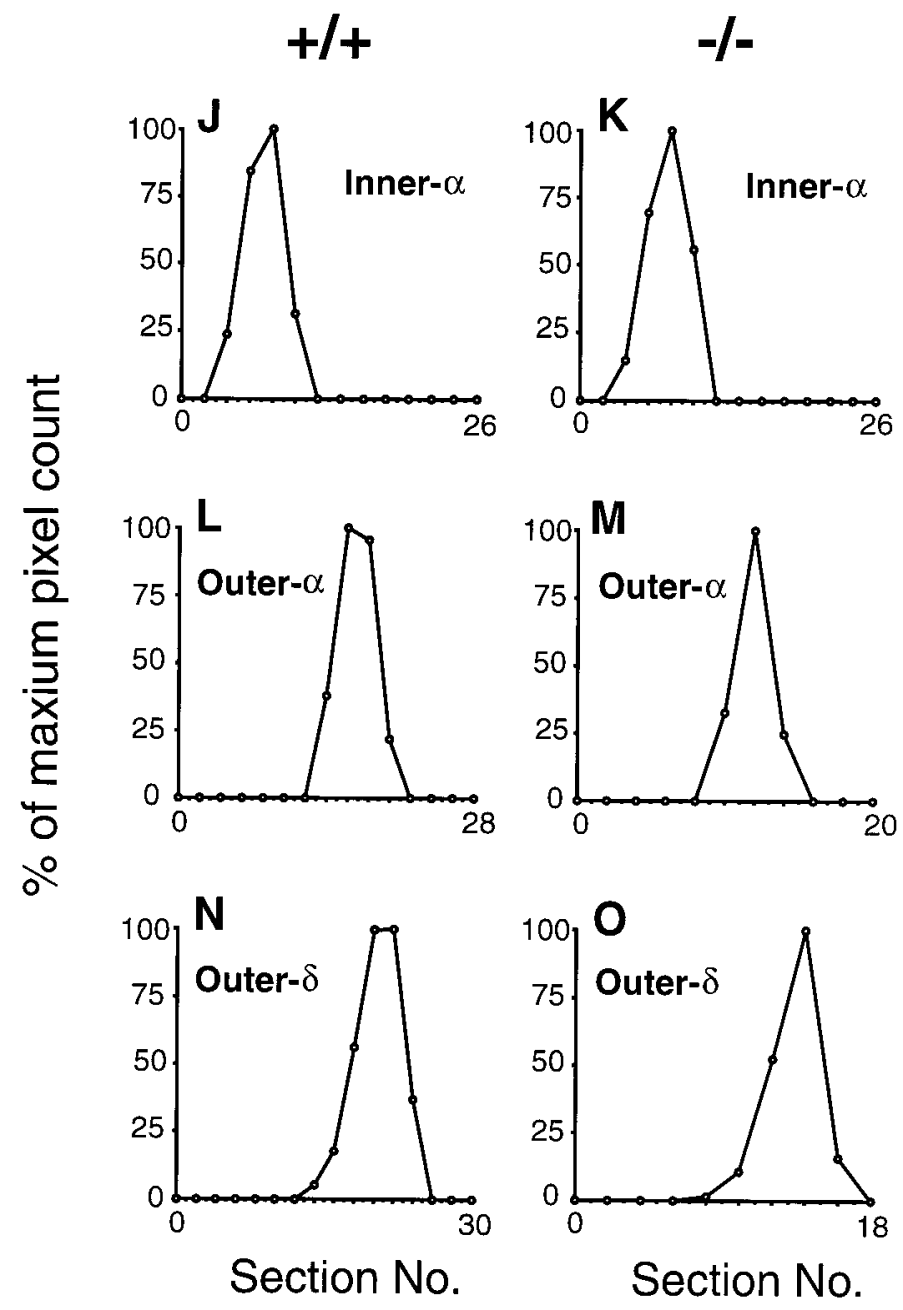

Figure 5 continued.

arations showed a dopaminergic innervation, with a meshwork sheet of dendrites over the IPL-INL border, as well as some sparsely located somata in the inner part of the INL (Fig. $5 F, I$ ). Because this immunostaining pattern of dopaminergic amacrine cells was indistinguishable between the two genotypes, we used the $\mathrm{TH}-\mathrm{Ab}$-positive innervation of dopaminergic cells as a reference to determine dendritic stratification levels of individual LY-injected RGCs. Care was also taken to compare LY-injected RGCs at the similar eccentricity to avoid eccentricity-dependent variations of morphology and dendritic field of RGCs. Examples of this analysis are illustrated in Figure $5 D-I$.

On the basis of this approach, we could identify dendritic morphologies and stratification levels of $\alpha$ and $\delta$ cells. $\alpha$ Cells were subdivided into inner- $\alpha$ and outer- $\alpha$ cells. Dendrites of inner- $\alpha$ RGCs branched at the innermost part of the IPL far from dopaminergic innervation (Fig. $5 C, D, G$ ), whereas those of outer- $\alpha$ RGCs ramified in the middle of the IPL near, but not overlapping with, dopaminergic innervation (Fig. $5 C, E, H) . \delta$ Cells have also been classified as inner and outer cells (Peichl, 1989). Outer- $\delta$ RGCs were easily identified; the main dendritic plane was located in the outermost section of the IPL, which partly overlapped with dopaminergic innervation (Fig. $5 C, F, I$ ). However, it was difficult to assign inner- $\delta$ cells because of their dendritic localization at sublamina $b$ close to sublamina a. In addition, as reported previously (Tauchi et al., 1992), inner- $\delta$ cells, if they exist, represented a minor population of the $\delta$ cells (Table 1).

Figure 5 also illustrates typical dendritic branching patterns of inner- $\alpha$, outer- $\alpha$, and outer- $\delta$ cells. Inner- $\alpha$ and outer- $\alpha$ cells showed smooth, relatively non-overlapping dendrites (Fig. $5 D, E, G, H)$, whereas $\delta$ cells displayed thinner and more curving branches (Fig. $5 F, I$ ). As reported previously (Huxlin and Goodchild, 1997), inner- $\alpha$ cells could be further subdivided into two types, one showing a dense dendritic field (Fig. 5D,G) and the other displaying a relatively sparse dendritic field (data not shown). We classified these two cell types as inner- $\alpha$ cells in our investigation. This morphological analysis indicates that not only the dendritic branching patterns but also the dendritic fields of the three cell types are indistinguishable between mGluR6 ${ }^{-/-}$ and mGluR6 ${ }^{+/+}$genotypes.

To quantify the stratification levels of the three cell types, we measured the length of dendrites in each serial image section and plotted it against the thickness of the IPL (Fig. 5J-O). This analysis indicates that all three RGCs have well defined, monostratified dendrites and show no difference in their dendritic stratification levels nor in the width of dendritic distribution between the two genotypes.

Table 1 summarizes the number of the four cell types of wild-type and mGluR6 knock-out mice according to the cell classification described above. The data indicates no difference in relative number of the four cell types between the two genotypes. Thus, the results demonstrate that, despite absence of mGluR6 expression, both $\alpha$ and $\delta$ RGCs maturate normally in adult retina and are able to extend monostratified dendrites to cell typespecific layers.

\section{Development of immature RGCs}

It is possible that mGluR6 deficiency may affect the maturation process of RGCs at early stages of retinal development. Therefore, we examined RGCs at postnatal day 12, just before eyeopening, because it has been reported that at a similar postnatal period (12-15 d), cat retinal RGCs exhibit conspicuous immature morphological features but have already differentiated into cell

\section{Table 1. The number of four types of RGCs}

\begin{tabular}{|c|c|c|c|c|c|c|c|}
\hline Genotypes & Ages & Animals & Retinae & Inner- $\alpha$ & Outer- $\alpha$ & Inner- $\delta^{*}$ & Outer- $\delta$ \\
\hline Wild-type & $7-8$ weeks & 3 & 5 & 24 & 18 & 2 & 15 \\
\hline Knock-out & $7-8$ weeks & 3 & 5 & 27 & 18 & 2 & 20 \\
\hline Wild-type & postnatal day 12 & 2 & 3 & $18(5)$ & $10(1)$ & $2(1)$ & $11(0)$ \\
\hline Knock-out & postnatal day 12 & 2 & 4 & $21(5)$ & $12(0)$ & $3(1)$ & $21(1)$ \\
\hline
\end{tabular}

Four types of RGCs analyzed in this study are summarized. The number in parentheses indicates the number of RGCs that show immature dendritic stratification.

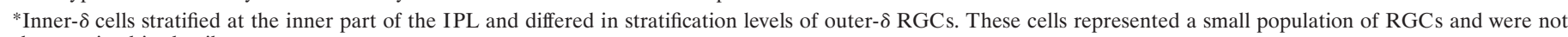
characterized in detail. 
types closely resembling those of adult cells (Ramoa et al., 1987, 1988; Dann et al., 1988). To investigate morphological immaturity and dendritic stratification levels of developing RGCs, we focused on RGCs with large- to medium-sized somata and adopted the above mentioned approach, which combined LY injection of RGCs and $\mathrm{TH}-\mathrm{Ab}$ immunostaining of dopaminergic amacrine cells. Developing RGCs identified here exhibited several immature features (Fig. 6). They showed extensive dendritic branches and much larger numbers of somatic and dendritic spines than in adults. Despite these immature properties, RGCs were well identified using dopaminergic innervation as a reference. Most of the RGCs, like adult cells, showed distinct dendritic monostratification in either the inner or outer part of the IPL. Therefore, immature RGCs were classified as inner- $\alpha$-like, outer- $\alpha$-like, and $\delta$-like RGCs. Remarkably, however, some of the inner- $\alpha$-like RGCs, whose main dendritic branches were located at the inner part (sublamina b) of the IPL, clearly extended their peripheral branches to the outer part (sublamina a) of the IPL (Fig. 6). Similar immature multistratification of inner- $\alpha$-like RGCs into two sublaminae were observed in both wild-type and mGluR6 knock-out mice (Fig. 6).

On the basis of cell classification described above, we calculated the number of different cell types in wild-type and mGluR6 knock-out mice at postnatal day 12 (Table 1). In addition to inner- $\alpha$-like cells, multistratified outer- $\alpha$-like and outer- $\delta$-like cells were also observed, but this incidence was very rare in both cell types (Table 1). An important observation of this analysis is that the incidence of immature dendritic stratifications of different cells is comparable between the two genotypes. The results strongly suggest that there is no significant difference in maturation of both $\alpha$ and $\delta$ cells in mGluR6 knock-out mice.

\section{DISCUSSION}

ON-OFF segregation is of fundamental importance in discriminating light and dark signals (Dowling, 1987) and in promoting the detection of both weak contrasts and rapid changes in light intensity (Schiller, 1992). Considerable evidence has indicated the role of mGluR6 in synaptic transmission of ON bipolar cells in both rod and cone systems. mGluR6 is confined at postsynaptic dendritic tips of both rod and cone ON bipolar cells (Nomura et al., 1994; Vardi and Morigiwa, 1997). Furthermore, mGluR6 shows an agonist profile consistent with the property of the L-AP-4-sensitive mGluR reported in ON bipolar cells (Nakajima et al., 1993). Ablation of mGluR6 expression by gene targeting abolishes not only $\mathrm{ON}$ responses recorded at the superior colliculus but also the b-wave of electroretinogram that reflects $\mathrm{ON}$ bipolar cell activity (Masu et al., 1995). In the retina of mGluR6 knock-out mice, the phosphorylated cAMP-responsive element binding protein and c-fos are not induced in response to light stimulation (Yoshida et al., 1998). Furthermore, consistent with the role of $\mathrm{ON}-\mathrm{OFF}$ segregation in visual detection, these knockout mice are markedly impaired in both detecting weak visual contrasts and responding rapidly to light exposure (Iwakabe et al., 1997). Nevertheless, mGluR6 knock-out mice can respond to visual inputs and exhibit light-stimulated induction of c-fos in suprachiasmatic nucleus (Iwakabe et al., 1997). Sugihara et al. (1997) recently observed that, under certain illumination conditions, mGluR6 knock-out mice generate a unique slow ON response that clearly differs from the ON response of wild-type mice. Although the mechanism underlying the appearance of such a slowly evoking ON response remains to be determined (but see Iwakabe et al., 1997; Sugihara et al., 1997; also below),
mGluR6 knock-out mice provide a unique opportunity to investigate the role of glutamate-mediated activity of $\mathrm{ON}$ bipolar cells during $\mathrm{ON}-\mathrm{OFF}$ network formation. To address this question, we combined several different approaches: the localization and axonal stratification of $\mathrm{ON}$ bipolar cells with the aid of lacZexpressing transgenic mice; immunohistological characterization of the cellular organization of several amacrine cells and expression patterns of other mGluR subtypes; and intracellular LY injection to analyze morphology and dendritic stratifications of mature and developing RGCs. The combination of these different approaches has allowed us to precisely assign the stratifications of ON bipolar and of distinct amacrine cells, in addition to developing and mature RGCs.

Immature cat RGCs initially possess multistratified dendrites, and, during the time of synaptic formation between bipolar cells and RGCs, these dendrites gradually monostratify into $\mathrm{ON}$ and OFF sublaminae (Maslim and Stone, 1986, 1988; Dann et al., 1988). On the basis of L-AP-4-evoked inhibitory effects on dendritic segregation of developing RGCs, it has been proposed that glutamate-mediated synaptic activation plays a key role in the synaptic formation between bipolar cells and RGCs (Bodnarenko and Chalupa, 1993; Bodnarenko et al., 1995; Bisti et al., 1998). In this investigation, we demonstrate that, despite the dramatic effects of mGluR6 deficiency on ON responses, this deficiency causes no alteration in the cellular organization of bipolar cells, amacrine cells, and RGCs nor in the stratifications of both ON bipolar cells and developing and mature RGCs. In our investigation, we focused on $\alpha$ and $\delta$ cells because the dendritic ON-OFF segregation of these cells could be easily identified after intracellular LY injection. In comparison, Chalupa and his associates (Bodnarenko and Chalupa, 1993; Bodnarenko et al., 1995; Bisti et al., 1998) investigated the inhibitory effect of L-AP-4 on immature $\beta$-RGCs, using the lipophilic tracer DiI implanted into optic nerve fibers. In our hands, LY injection into cells with smallersized somata identified a certain number of bushy and well branched small RGCs, which resembled cat $\beta$ cells. Although more quantitative experiments are necessary, we observed that these cells distinctly and comparably monostratify into either sublamina a or sublamina $b$ in the adult retinae of wild-type and mGluR6 knock-out mice. One limitation of our study is the lack of direct evidence indicating that immature $\alpha$-like and $\delta$-like RGCs differentiate into corresponding mature cell types during retinal development. However, the morphological characteristics of mouse $\alpha$-like RGCs completely agree with those of immature $\alpha$ cells characterized in the cat retina (Ramoa et al., 1987, 1988; Dann et al., 1988). Therefore, similar to their cat counterparts, it is reasonable to conclude that some immature $\alpha$-like RGCs multistratify at two laminae. Importantly, such multistratification of immature $\alpha$-like RGCs is comparable between wild-type and mGluR6 knock-out mice.

Both intraocular L-AP-4 injection and mGluR6 deficiency block induction of ON responses. However, the effects of L-AP-4 injection and mGluR6 deficiency are clearly different in dendritic ON-OFF segregation of RGCs during retinal development. This observation, together with the results of Chalupa and coworkers (Bodnarenko and Chalupa, 1993; Bodnarenko et al., 1995; Bisti et al., 1998), sheds much insight into possible mechanisms that may underlie the formation of the ON-OFF network in the IPL. The first possibility is that glutamate release is indispensable for ON-OFF segregation in the IPL. L-AP-4 hyperpolarizes ON bipolar cells and reduces glutamate release. In contrast, it is expected, although not investigated, that mGluR6 ablation results 

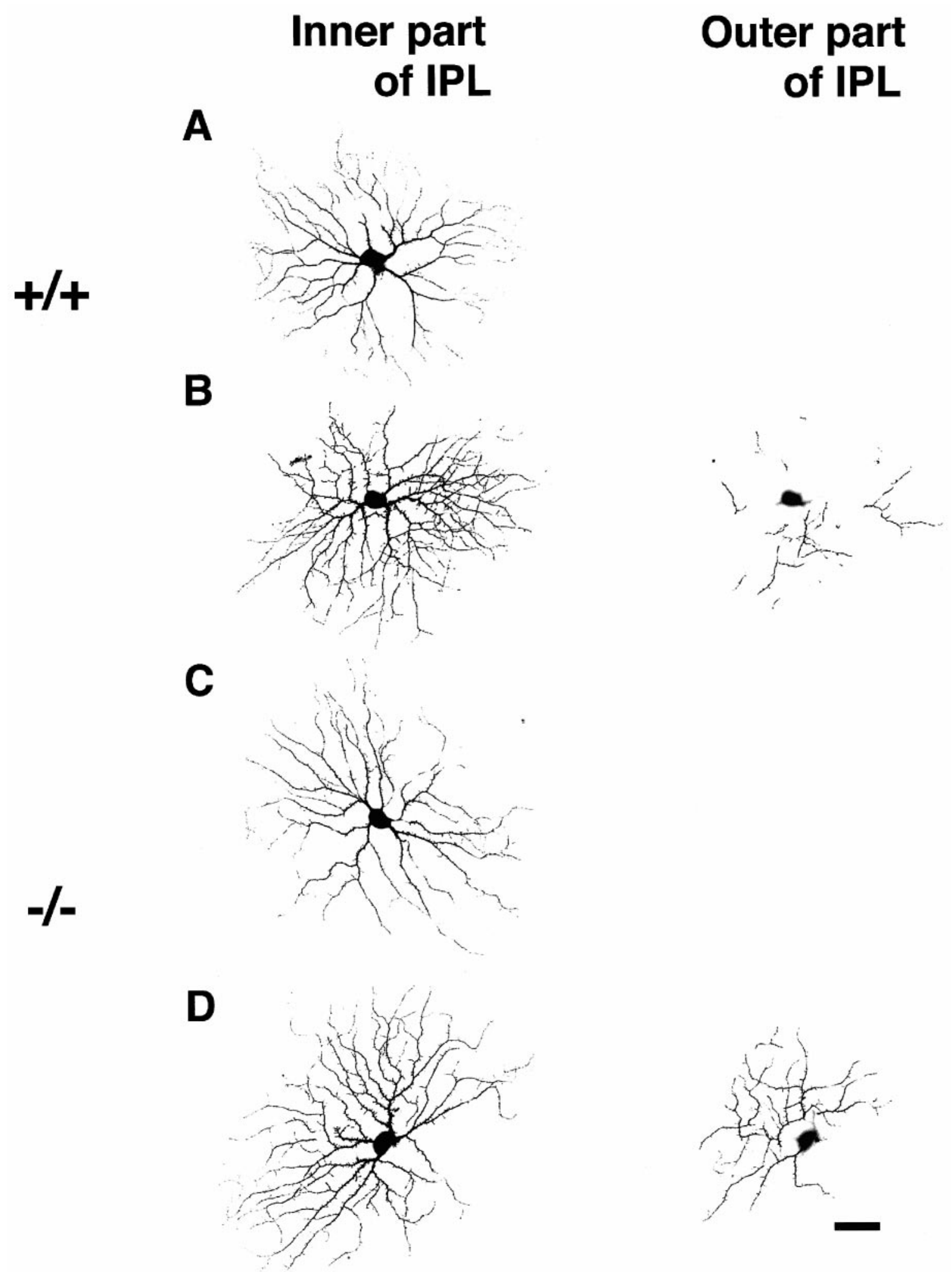

Figure 6. Confocal images of inner- $\alpha$-like RGCs of wild-type $(+/+)$ and mGluR6 knock-out $(-/-)$ mice at postnatal day 12 . The left images show dendritic branches at the inner part of the IPL (the main dendritic plane), and the right images indicate the presence and absence of peripheral dendritic branches at the outer part of the IPL. These inner- $\alpha$-like RGCs show immature morphology. Cells shown in $A$ and $C$ monostratify at the inner part of the IPL, whereas those shown in $B$ and $D$ also extend their peripheral dendrites to the outer part of the IPL. Eccentricity: $A, 1.9 \mathrm{~mm} ; B, 1.3 \mathrm{~mm}$; , $1.2 \mathrm{~mm} ; D, 1.5 \mathrm{~mm}$. Scale bar, $50 \mu \mathrm{m}$. 
in a high level of cGMP within ON bipolar cells, leading to an enhancement of glutamate release from these cells. Therefore, if the mechanism for ON-OFF segregation in the IPL depends on glutamate release, the effects of L-AP-4 injection on ON-OFF segregation should be different from those of mGluR6 ablation. Second, L-AP-4 acts not only on mGluR6 but also on other subtypes of group III mGluRs. Therefore, an alternative possibility is that multiple actions of L-AP-4 in glutamatergic transmission are required for L-AP-4-mediated retardation of dendritic segregation of developing RGCs. L-AP-4-mediated glutamatergic neurotransmission may also modulate other neurotransmitters, and such neurotransmitters may participate in the remodeling of synaptic connections of developing RGCs. It has recently been reported that GABAergic transmission differentially modulates ON and OFF RGCs during a period when the axon terminals of RGCs are segregated into ON and OFF pathways (Fischer et al., 1998). Because a temporally regulated neuronal activity is thought to be critical for developmental remodeling of synaptic connections, GABAergic transmission may also be involved in refining the neural network. Third, a unique slow ON signal remains in mGluR6 knock-out mice (Sugihara et al., 1997). This activity may be sufficient for the remodeling of immature RGCs. In wild-type retina, mGluR7 has been shown to be present at presynaptic ribbon structures of cone ON and OFF bipolar cells but not at postsynaptic sites of any bipolar cells (Brandstätter et al., 1996). Interestingly, the present investigation has revealed that mGluR7 immunoreactivity is distributed at the OPL-INL border in mGluR6 knock-out mice. Both mGluR6 and mGluR7 belong to group III mGluRs and respond to L-AP-4 (Okamoto et al., 1994). This ectopic mGluR7 may explain the unusual ON response that was observed in mGluR6 knock-out mice under particular illumination conditions (Sugihara et al., 1997). Because mGluR7 knock-out mice grow normally (Masugi et al., 1999), it would be interesting to address whether double knock-out mice of mGluR6 and mGluR7 lose the unusual ON response and, if so, whether the deficiency of both mGluR6 and mGluR7 may affect developmental dendritic segregation of ON and OFF RGCs.

\section{REFERENCES}

Akazawa C, Ohishi H, Nakajima Y, Okamoto N, Shigemoto R, Nakanishi S, Mizuno N (1994) Expression of mRNAs of L-AP4-sensitive metabotropic glutamate receptors (mGluR4, mGluR6, mGluR7) in the rat retina. Neurosci Lett 171:52-54.

Bisti S, Gargini C, Chalupa LM (1998) Blockade of glutamate-mediated activity in the developing retina perturbs the functional segregation of ON and OFF pathways. J Neurosci 18:5019-5025.

Blendy JA, Kaestner KH, Schmid W, Gass P, Schütz G (1996) Targeting of the CREB gene leads to up-regulation of a novel CREB mRNA isoform. EMBO J 15:1098-1106.

Bodnarenko SR, Chalupa LM (1993) Stratification of ON and OFF ganglion cell dendrites depends on glutamate-mediated afferent activity in the developing retina. Nature 364:144-146.

Bodnarenko SR, Jeyarasasingam G, Chalupa LM (1995) Development and regulation of dendritic stratification in retinal ganglion cells by glutamate-mediated afferent activity. J Neurosci 15:7037-7045.

Boycott BB, Wässle H (1974) The morphological types of ganglion cells of the domestic cat's retina. J Physiol (Lond) 240:397-419.

Brandstätter JH, Koulen P, Kuhn R, van der Putten H, Wässle H (1996) Compartmental localization of a metabotropic glutamate receptor (mGluR7): two different active sites at a retinal synapse. J Neurosci 16:4749-4756.

Dann JF, Buhl EH, Peichl L (1988) Postnatal dendritic maturation of $\alpha$ and $\beta$ ganglion cells in cat retina. J Neurosci 8:1485-1499.

de la Villa P, Kurahashi T, Kaneko A (1995) L-glutamate-induced responses and cGMP-activated channels in three subtypes of retinal bipolar cells dissociated from the cat. J Neurosci 15:3571-3582.
Dowling JE (1987) The retina: an approachable part of the brain. Cambridge, MA: Harvard UP.

Duvoisin RM, Zhang C, Ramonell K (1995) A novel metabotropic glutamate receptor expressed in the retina and olfactory bulb. J Neurosci 15:3075-3083.

Famiglietti Jr E, Kolb H (1976) Structural basis for ON- and OFF-center responses in retinal ganglion cells. Science 194:193-195.

Fischer KF, Lukasiewicz PD, Wong RO (1998) Age-dependent and cell class-specific modulation of retinal ganglion cell bursting activity by GABA. J Neurosci 18:3767-3778.

Hartveit E, Brandstätter JH, Enz R, Wässle H (1995) Expression of the mRNA of seven metabotropic glutamate receptors (mGluR1 to 7) in the rat retina. An in situ hybridization study on tissue sections and isolated cells. Eur J Neurosci 7:1472-1483.

Hummler E, Cole TJ, Blendy JA, Ganss R, Aguzzi A, Schmid W, Beermann F, Schütz G (1994) Targeted mutation of the CREB gene: compensation within the CREB/ATF family of transcription factors. Proc Natl Acad Sci USA 91:5647-5651.

Huxlin KR, Goodchild AK (1997) Retinal ganglion cells in the albino rat: revised morphological classification. J Comp Neurol 385:309-323.

Iwakabe H, Katsuura G, Ishibashi C, Nakanishi S (1997) Impairment of pupillary responses and optokinetic nystagmus in the mGluR6-deficient mouse. Neuropharmacology 36:135-143.

Koulen P, Malitschek B, Kuhn R, Wässle H, Brandstätter JH (1996) Group II and group III metabotropic glutamate receptors in the rat retina: distributions and developmental expression patterns. Eur J Neurosci 8:2177-2187.

Koulen P, Kuhn R, Wässle H, Brandstätter JH (1997) Group I metabotropic glutamate receptors mGluR $1 \alpha$ and mGluR5a: localization in both synaptic layers of the rat retina. J Neurosci 17:2200-2211.

Maslim J, Stone J (1986) Synaptogenesis in the retina of the cat. Brain Res 373:35-48.

Maslim J, Stone J (1988) Time course of stratification of the dendritic fields of ganglion cells in the retina of the cat. Dev Brain Res 44:87-93.

Masu M, Iwakabe H, Tagawa Y, Miyoshi T, Yamashita M, Fukuda Y, Sasaki H, Hiroi K, Nakamura Y, Shigemoto R, Takada M, Nakamura K, Nakao K, Katsuki M, Nakanishi S (1995) Specific deficit of the ON response in visual transmission by targeted disruption of the mGluR6 gene. Cell 80:757-765.

Masugi M, Yokoi M, Shigemoto R, Muguruma K, Watanabe Y, Sansig G, van der Putten H, Nakanishi S (1999) Metabotropic glutamate receptor subtype 7 ablation causes deficit in fear response and conditioned taste aversion. J Neurosci 19:955-963.

Miller RF, Slaughter MM (1986) Excitatory amino acid receptors of the retina: diversity of subtypes and conductance mechanism. Trends Neurosci 9:211-218.

Mitrofanis J, Maslim J, Stone J (1988) Catecholaminergic and cholinergic neurons in the developing retina of the rat. J Comp Neurol 276:343-359.

Nakajima Y, Iwakabe H, Akazawa C, Nawa H, Shigemoto R, Mizuno N, Nakanishi S (1993) Molecular characterization of a novel retinal metabotropic glutamate receptor mGluR6 with a high agonist selectivity for L-2-amino-4-phosphonobutyrate. J Biol Chem 268:11868-11873.

Nakanishi S (1995) Second-order neurones and receptor mechanisms in visual and olfactory information processing. Trends Neurosci 18:359-364.

Nawy S, Jahr CE (1990) Suppression by glutamate of cGMP-activated conductance in retinal bipolar cells. Nature 346:269-271.

Nawy S, Jahr CE (1991) cGMP-gated conductance in retinal bipolar cells is suppressed by the photoreceptor transmitter. Neuron 7:677-683.

Negishi K, Kato S, Teranishi T (1988) Dopamine cells and rod bipolar cells contain protein kinase C-like immunoreactivity in some vertebrate retinas. Neurosci Lett 94:247-252.

Nelson R, Famiglietti Jr E, Kolb H (1978) Intracellular staining reveals different levels of stratification for on- and off-center ganglion cells in cat retina. J Neurophysiol 41:472-483.

Nomura A, Shigemoto R, Nakamura Y, Okamoto N, Mizuno N, Nakanishi S (1994) Developmentally regulated postsynaptic localization of a metabotropic glutamate receptor in rat rod bipolar cells. Cell 77:361-369.

Ohishi H, Shigemoto R, Nakanishi S, Mizuno N (1993) Distribution of the messenger RNA for a metabotropic glutamate receptor, mGluR2, in the central nervous system of the rat. Neuroscience 53:1009-1018.

Okamoto N, Hori S, Akazawa C, Hayashi Y, Shigemoto R, Mizuno N, Nakanishi S (1994) Molecular characterization of a new metabotropic 
glutamate receptor mGluR7 coupled to inhibitory cyclic AMP signal transduction. J Biol Chem 269:1231-1236.

Pasteels B, Rogers J, Blachier F, Pochet R (1990) Calbindin and calretinin localization in retina from different species. Vis Neurosci 5:1-16.

Peichl L (1989) $\alpha$ and $\delta$ ganglion cells in the rat retina. J Comp Neurol 286:120-139.

Peichl L, Wässle H (1981) Morphological identification of on- and offcentre brisk transient (Y) cells in the cat retina. Proc R Soc Lond B Biol Sci 212:139-153.

Ramoa AS, Campbell G, Shatz CJ (1987) Transient morphological features of identified ganglion cells in living fetal and neonatal retina. Science 237:522-525.

Ramoa AS, Campbell G, Shatz CJ (1988) Dendritic growth and remodeling of cat retinal ganglion cells during fetal and postnatal development. J Neurosci 8:4239-4261.

Sasaki T, Kaneko A (1996) L-Glutamate-induced responses in OFF-type bipolar cells of the cat retina. Vision Res 36:787-795.

Schiller PH (1992) The ON and OFF channels of the visual system. Trends Neurosci 15:86-92.

Shiells RA, Falk G (1990) Glutamate receptors of rod bipolar cells are linked to a cyclic GMP cascade via a G-protein. Proc R Soc Lond B Biol Sci 242:91-94.

Shigemoto R, Nakanishi S, Mizuno N (1992) Distribution of the mRNA for a metabotropic glutamate receptor (mGluR1) in the central nervous system: an in situ hybridization study in adult and developing rat. J Comp Neurol 322:121-135.

Shigemoto R, Kinoshita A, Wada E, Nomura S, Ohishi H, Takada M, Flor PJ, Neki A, Abe T, Nakanishi S, Mizuno N (1997) Differential presynaptic localization of metabotropic glutamate receptor subtypes in the rat hippocampus. J Neurosci 17:7503-7522.
Sugihara H, Inoue T, Nakanishi S, Fukuda Y (1997) A late ON response remains in visual response of the mGluR6-deficient mouse. Neurosci Lett 233:137-140.

Tauchi M, Masland RH (1984) The shape and arrangement of the cholinergic neurons in the rabbit retina. Proc R Soc Lond B Biol Sci 223:101-119.

Tauchi M, Morigiwa K, Fukuda Y (1992) Morphological comparisons between outer and inner ramifying $\alpha$ cells of the albino rat retina. Exp Brain Res 88:67-77.

Ueda Y, Iwakabe H, Masu M, Suzuki M, Nakanishi S (1997) The mGluR6 5' upstream transgene sequence directs a cell-specific and developmentally regulated expression in retinal rod and ON-type cone bipolar cells. J Neurosci 17:3014-3023.

Vardi N, Morigiwa K (1997) ON cone bipolar cells in rat express the metabotropic receptor mGluR6. Vis Neurosci 14:789-794.

Voigt T (1986) Cholinergic amacrine cells in the rat retina. J Comp Neurol 248:19-35.

Wässle H, Boycott BB (1991) Functional architecture of the mammalian retina. Physiol Rev 71:447-480.

Wulle I, Schnitzer J (1989) Distribution and morphology of tyrosine hydroxylase-immunoreactive neurons in the developing mouse retina. Dev Brain Res 48:59-72.

Yamashita M, Wässle H (1991) Responses of rod bipolar cells isolated from the rat retina to the glutamate agonist 2-amino-4phosphonobutyric acid (APB). J Neurosci 11:2372-2382.

Yoshida K, Imaki J, Okamoto Y, Iwakabe H, Fujisawa H, Matsuda A, Nakanishi S, Matsuda H, Hagiwara M (1998) CREB-induced transcriptional activation depends on mGluR6 in rod bipolar cells. Mol Brain Res 57:241-247. 